\title{
Correction to: Land Use Changes Assessment using a triangulated framework: Perception Interviews, Land-Use/Land Cover Observation, and Spatial Planning Analysis in Tanjung Batu and Derawan Island, Indonesia
}

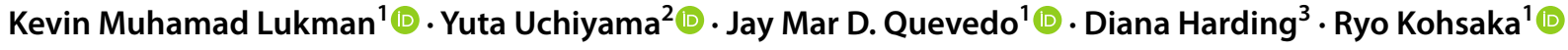

Published online: 19 February 2022

(c) The Authors 2022

\section{Correction to: Human Ecology (2021) 49:551-564 https://doi.org/10.1007/s10745-021-00253-w}

The article Land Use Changes Assessment using a triangulated framework: Perception Interviews, Land-Use/Land Cover Observation, and Spatial Planning Analysis in Tanjung Batu and Derawan Island, Indonesia, written by Kevin Muhamad Lukman, Yuta Uchiyama, Jay Mar D. Quevedo, Diana Harding, Ryo Kohsaka, was originally published Online First without Open Access. After publication in volume 49, issue 5, pages 551-564 the author decided to opt for Open Choice and to make the article an Open Access publication. Therefore, the copyright of the article has been changed to () The Authors 2021 and the article is forthwith distributed under the terms of the Creative Commons Attribution 4.0 International License, which permits use, sharing, adaptation, distribution and reproduction in any medium or format, as long as you give appropriate credit to the original author(s) and the source, provide a link to the Creative Commons licence, and indicate if changes were made. The images or other third party material in this article are included in the article's Creative Commons licence,

The original article can be found online at https://doi.org/10.1007/ s10745-021-00253-w.

Ryo Kohsaka

kohsaka@hotmail.com

1 Graduate School of Environmental Studies, Tohoku

University, Aoba, 468-1, Aramaki, Aoba-ku,

Sendai 980-8572, Japan

2 Graduate School of Environmental Studies, Nagoya University, D2-1(510), Furo-cho, Chikusa-ku,

Nagoya 464-8601, Japan

3 Department of Psychology, Padjajaran University, Jl. Raya Bandung Sumedang KM.21, Hegarmanah, Jatinangor, Sumedang, Jawa Barat 45363, Indonesia unless indicated otherwise in a credit line to the material. If material is not included in the article's Creative Commons licence and your intended use is not permitted by statutory regulation or exceeds the permitted use, you will need to obtain permission directly from the copyright holder. To view a copy of this licence, visit http://creativecommons. org/licenses/by/4.0/.

The original article has been corrected.

Open Access This article is licensed under a Creative Commons Attribution 4.0 International License, which permits use, sharing, adaptation, distribution and reproduction in any medium or format, as long as you give appropriate credit to the original author(s) and the source, provide a link to the Creative Commons licence, and indicate if changes were made. The images or other third party material in this article are included in the article's Creative Commons licence, unless indicated otherwise in a credit line to the material. If material is not included in the article's Creative Commons licence and your intended use is not permitted by statutory regulation or exceeds the permitted use, you will need to obtain permission directly from the copyright holder. To view a copy of this licence, visit http://creativecommons.org/licenses/by/4.0/.

Publisher's Note Springer Nature remains neutral with regard to jurisdictional claims in published maps and institutional affiliations. 